\title{
Varieties of state interventionism in financial policy in the aftermath of the 2008 global crisis *
}

\author{
Maria Antonieta Del Tedesco Lins **
}

\begin{abstract}
Thanks to lessons learned and reforms implemented after the financial crises of the late 1990s, most emerging market economies proved relatively resilient to the 2008 global crisis. Yet to cope with the turbulence that ensued, several interventions by monetary authorities in foreign exchange and capital markets were carried out. The literature on Latin American financial systems and central bank reform tends to emphasize international actors and pressures as key determinants of policy change. In contrast, this paper raises the hypothesis that domestic concerns were the main drivers of financial policymaking after the 2008 crisis even in countries with different institutional arrangements and macroeconomic trajectories such as Brazil, Mexico and Argentina. Through a comparative case study analysis, it is concluded that indeed the three countries' approaches to exchange markets and capital controls contradicted international perceptions and even the IMF's stance on foreign exchange policies and the management of capital flows. By pursuing more autonomy and responding to domestic priorities, each of the three countries adopted different policy measures.
\end{abstract}

Keywords: Financial policy; Financial integration; Emerging economies; Latin American economies.

\section{Resumo}

\section{Variedades de intervencionismo estatal em política financeira após a crise global de 2008}

Graças às lições aprendidas e às reformas implementadas após as crises financeiras do final dos anos 1990, muitas economias emergentes se mostraram relativamente resilientes na crise global de 2008. Para enfrentar a turbulência originada, foram revistas políticas para os mercados cambiais e controles de capitais. A literatura sobre os sistemas financeiros da América Latina e sobre as reformas dos bancos centrais enfatiza o papel de atores e pressões internacionais sobre o policymaking. O trabalho argumenta que questões domésticas foram determinantes da política financeira após a crise de 2008, mesmo em países como Argentina, Brasil e México, com distintos arranjos institucionais e trajetórias macroeconômicas. Por meio de uma análise de estudo de caso comparativo, conclui-se que as políticas cambial e de controle de capitais dos três países não se alinham com uma visão internacional dominante e tampouco convergem com a posição do FMI sobre câmbio e a gestão dos fluxos de capital. Na busca por maior autonomia e atendendo às prioridades políticas domésticas, cada um dos três países adotou medidas distintas.

Palavras-chave: Política financeira; Integração financeira; Economias emergentes; Economias latino-americanas. JEL F330, G180, G010.

\section{Introduction}

Argentina, Brazil and Mexico, notwithstanding some shared common economic experiences - such as high inflation, foreign debt crises, adoption of heterodox macroeconomic

\footnotetext{
* Artigo recebido em 7 de janeiro de 2019 e aprovado em 30 de janeiro de 2020.

* Associate professor at the Instituto de Relações Internacionais da Universidade de São Paulo (IRI / USP), São Paulo, SP, Brasil. E-mail: madtlins@ usp.br. ORCID: https://orcid.org/0000-0002-5332-0687.
} 
adjustment plans under the supervision of the International Monetary Fund, similar macroeconomic structures, pegged exchange rate regimes and financial liberalization - ended up taking distinct paths following the financial crises that hit developing markets during the 1990s. In all three cases, substantial economic policy restructurings were implemented after the crises. Indeed, the relative resilience of the emerging economies in the face of the global financial crisis of 2008 can be explained, to a large extent, by the economic reforms undertaken in response to each country's own series of economic crises. Said reforms included institutional transformations that permitted fiscal improvements and new efforts to regulate and supervise the financial systems.

While Argentina, Brazil and Mexico did implement diverse reforms to their respective financial sector policies after the 1990s crises, these changes do not appear to have been implemented at the behest of external pressures, either as a reaction to cyclical changes in the world economy or as a concession to multilateral or other global players. Rather these policies appear to have been a response to domestic priorities. In fact, the use of capital and currency controls appears to be coherent with the existing domestic political movements of the time. External pressures are considered here as a set of events originating outside the country, such as economic shocks, crises, dissemination of opinions and political guidelines at the international level and conditionalities and policies proposed by international organizations whose developments and impacts could influence the countries' financial policymaking.

This paper is an exercise of comparative political economy as it aims to carry out a comparative analysis of the financial policies of the three countries from the beginning of the 2000s until 2014, with the objective of identifying the set of political factors that acted on the choices of exchange rate policy and capital controls in order to define the pattern of financial integration of each country. The hypothesis to be appraised is that, despite the fact that policy motivation cannot be attributed solely to domestic factors or external events, the comparative analysis of the three countries' financial policies - even considering the substantive distinctions between the three cases - indicates that domestic policy was imperative in determining the financial measures adopted by each country and their global financial insertion. The time frame of the study looks to (i) incorporate financial reforms and policy switches that were implemented after the cycle of financial crises in the 1990s and the beginning of the 2000s; (ii) separate from the analysis the profound political changes that Brazil and Argentina have undergone since 2014, with the shift in Brazil's economic policy beginning in the second mandate of Dilma Rousseff and her eventual impeachment, and the transition in governments in Argentina to Mauricio Macri. ${ }^{1}$

Albeit one large and two middle-sized economies, Brazil, Argentina, and Mexico are traditionally policy takers in the international monetary system regardless of the potential impacts of their economic policy shifts within the region. However, since their reinsertion in

(1) Despite the rise to power of an opposition party after seven decades of Partido Revolucionario Institucional - PRI rule, Mexico has not experienced a sharp political turnaround since 2000. 
the world financial markets in the 1990s and their respective macroeconomic stabilization processes, these countries could seek to achieve greater relevance in the international financial sphere, either through more intense market participation or greater importance in the global financial governance debate.

Much has been said about the long period of macroeconomic instability coupled with financial crises and erratic economic policymaking in Latin America (e.g. Stanley 2018, Wiesner 2008). However, a focused study of financial policies implemented by Argentina, Brazil and Mexico carried out through the lenses of their very distinct political developments seems to be missing: an analysis of the interdependence between politics and economic policymaking processes in the three largest Latin American economies. By comparing the respective financial policies against their political background, the paper proposes to retrace their evolution and outcomes to ultimately define the features of each country's global financial integration.

In a review essay on the recent developments of international monetary politics within the international political economy (IPE) scholarship, Cohen (2017) sheds light on the prevalence of state-based analyses and scarce contributions devoted to structural issues and the whole international monetary system. This study commits, in part, the same sin. Initially, it departs from national policy investigations, however, on the other hand, the comparative case study presented here intends to understand the financial insertion of three emerging nations that operate the global system to different degrees, belong to a set of new players and therefore seek strategies to position themselves in this system. How could they conciliate national priorities in an interdependent financial system and which policy solutions do they chose?

The monetary power theories will be borrowed to serve as guidelines for assessing the relative importance of each country in an increasingly integrated and complex international monetary and financial system, given its condition of emerging market economy. The role played by domestic politics on each country's financial policies will be evaluated based on theoretic categories relating money and power; money being considered in a broad sense, covering monetary and foreign exchange policies together with capital and financial accounts regulation, as Susan Strange (1990: 259) conceived it:

By the field of finance, I refer particularly to the system by which credit is created, bought and sold and by which the direction and use of capital is determined. Although it is hard to separate this entirely from what might be called the field of money - that is, the exchange rates between currencies - on account of the key role in both fields played by the rate of interest.

Notwithstanding the vast scholarship devoted to a so-called monetary power theory, the study elects to concentrate on specific contributions brought by Cohen's work $(2005,2006$, 2008, 2015, 2017).

The text has four sections besides this introduction. It starts by presenting the general economic situation of each of the three economies at the time of the 2008 global crisis. The 
following sections analyze financial policies specifically, starting with the foreign exchange designs within the framework of the macroeconomic policy and then the policies of capital control. The fourth section presents a comparison made by adapting the selected monetary power criteria to each case, followed by a synthetic analysis and finally the conclusion.

\section{The period immediately prior to the Great Recession}

In the period immediately prior to the global crisis, Argentina was experiencing twin surpluses (fiscal and current account), built up from the resurrection of its economy in the post 2002 era. The real economy was being driven by the commodity boom, and by a new type of macroeconomic populism established in 2007 (Labaqui, 2014; Damill; Frenkel, 2013, 2014; Fanelli, 2013).

The Brazilian economy also passed through a prosperous phase in 2008. After several years of fiscal discipline that restored a certain level of international credibility and some stability, an expansionist economic policy was being implemented, characterized by stimulus to domestic consumption and investment. As such, the countercyclical policies applied during the global crisis were above all an extension of the policies already in place.

The effects of the 2008 shock, on the contrary, impacted Mexico more harshly. In fact, Mexico saw the reversal of a trajectory of growth that had begun in 2002 and that was the result of higher global oil prices, increased exports to the United States, and growing remittances from abroad. This situation led to an increase in government spending up until 2008. However, the close relationship with the American economy condemned Mexico to endure more profound economic effects from the crisis, specifically via lower exports and a heavily depreciated currency.

Nevertheless, Mexico had a relatively fast recovery from the initial shock. According to the IMF report on the Mexican financial system, ${ }^{2}$ the adherence to an inflation targeting system since 1996 and a free-floating currency, combined with strict fiscal discipline, were the essential factors that explained the recuperation of the Mexican economy beginning in 2010 (IMF, 2012a). The restructuring of the financial system after 1995, its low external exposure and a moderate reaction from the central bank were characteristics of Mexican economic policy in reaction to the global crisis (Esquivel, 2015).

Despite their different economic situations upon the failure of Lehman Brothers in 2008, and the diversity of the overall macroeconomic policy established in these three countries, all three showed themselves capable of maintaining important amounts of foreign reserves, even considering the fairly less favorable situation of Argentina, whose reserves began to decline significantly in early 2007 (and only returned to growth in 2015) as shown in Graph 1.

(2) Mexico: Financial System Stability Assessment, March 2012. 


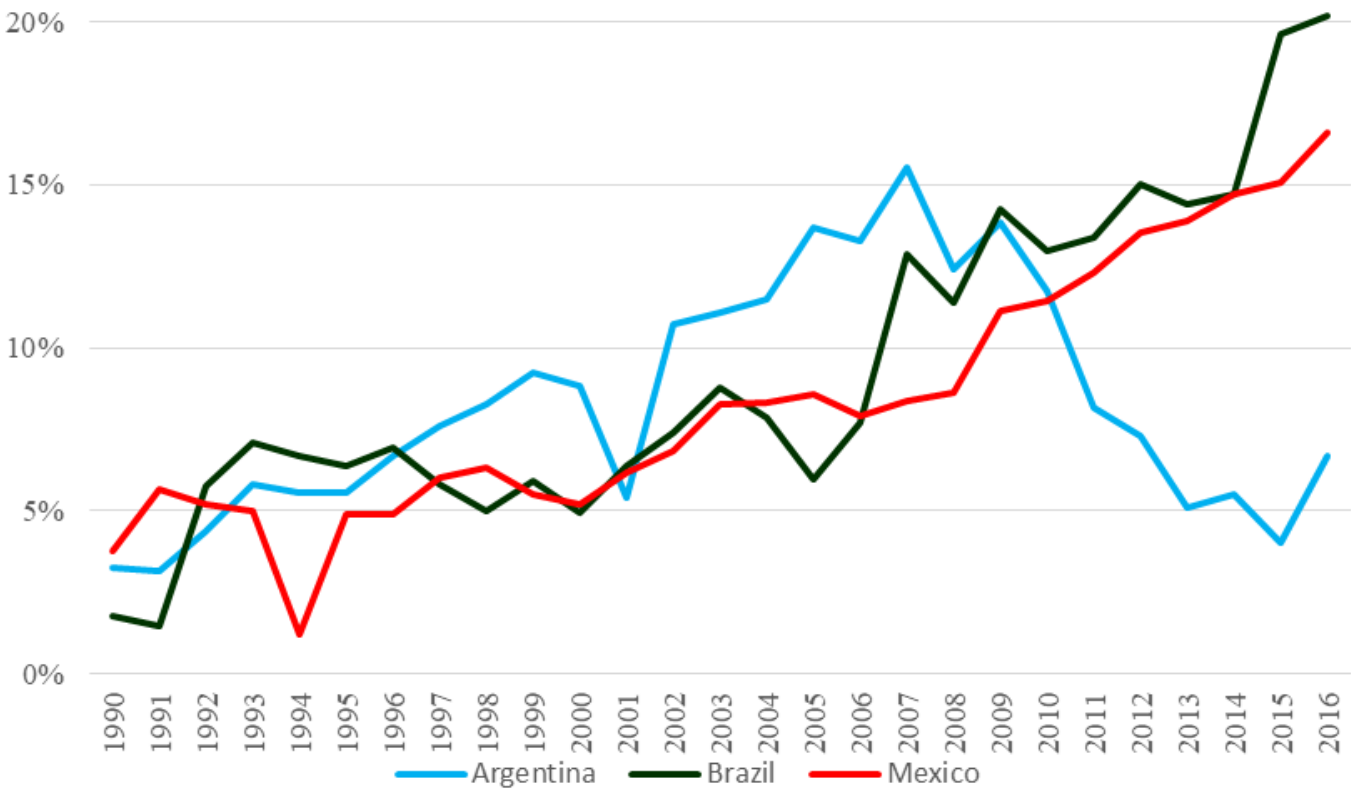

Source: World Bank data base.

Graph 2

Sovereign debt risk: EMBI - Emerging Markets Bond Index

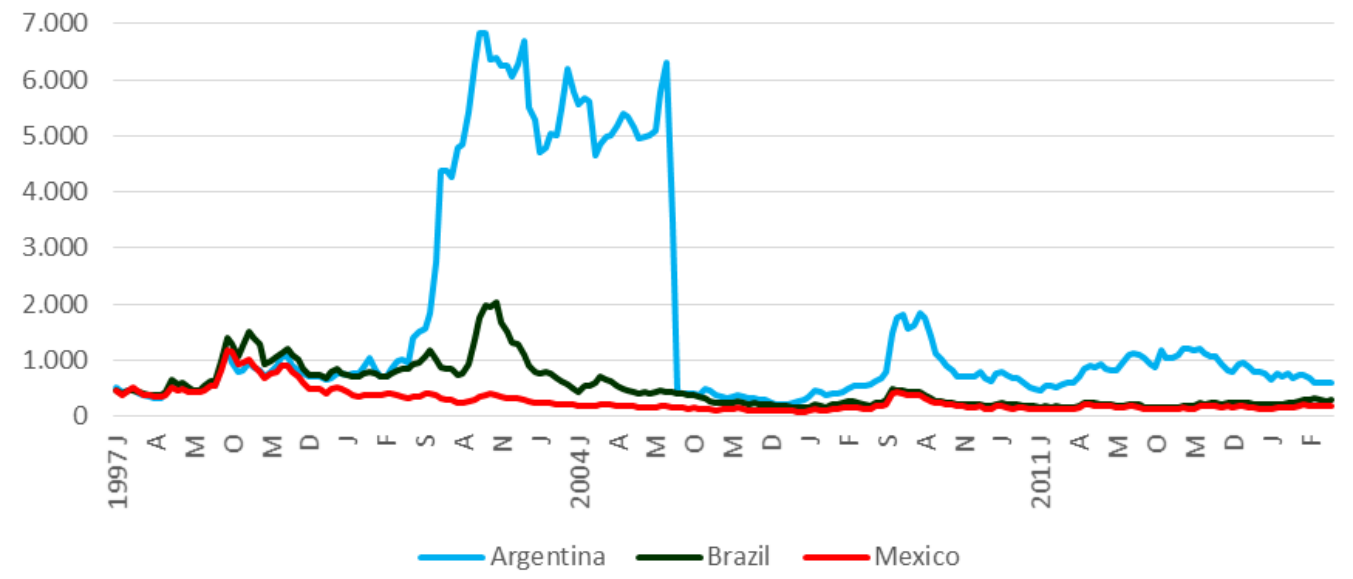

Source: J. P. Morgan

Note: The Emerging Markets Bond Index is a benchmark index for measuring the total return performance of international government bonds issued by emerging market countries that are considered sovereign (issued in something other than local currency) and that meet specific liquidity and structural requirements. 
Capital flight began in Argentina in 2007 when it became public knowledge that the official statistics institute was consistently underreporting the rate of inflation. From that point the credibility of the country's economic policy began to decline systematically, which can be confirmed by the prices of Argentine government bonds in international markets, and the rising spreads measuring the perceived risk of default (Damill; Frenkel, 2013). Graph 2 presents the evolution of the most utilized country risk indicator calculated by JPMorgan. The index clearly shows a rising trend in Argentina's sovereign risk in 2007, while during the same period the same indicator for Brazil and Mexico had a relatively stable evolution, which remained as such until the end of 2014 in the case of Brazil.

Reflecting on these movements, the inflows of portfolio investments into Argentina, Brazil, and Mexico were relatively unstable following the 2008 crisis. Aside from fluctuations in international markets, levels of foreign capital inflows were relatively unequal for the three countries during this period.

The erratic behavior of foreign capital was not only due to the significant diversities established between these three markets in the early 2000s, but can also be attributed to a shift in the global economy at the end of 2011. The large emerging economies decreased their growth rate which, combined with the new monetary policy in advanced economies and expectations for rising interest rates in these more secure markets, resulted in smaller capital inflows for emerging markets.

At the same time, capital controls were implemented by emerging economies, both in order to protect against reversals of capital inflows, but also as a tool to reduce sharp fluctuations in foreign exchange markets. Brazil was a pioneer in the use of taxes on capital to control capital flight. Mexico, on the other hand, was rewarded by the credit rating agencies for its conservative management of economic policy. In sum, emerging economies began to execute new economic policies or reform some existing ones - using capital controls, monetary policy, and more permissive fiscal agendas - and as such they brought new elements to the market and new configurations to their own policy repertoires.

The different positions of Argentina, Brazil, and Mexico could be understood by looking at the trajectory of their financial crises in the 1990s and 2000s. In addition to economic restrictions, domestic political dynamics played a crucial role in the selection of financial policy and in the international position of the three countries.

\section{Economic policy diffusion in the new millennium}

Economic policy suffered a number of changes during the period in focus. The issue of having an international currency was not relevant for the three countries in the period. Above all, their main concern was to consolidate their positions as stable economies and relevant 
players in the international financial system, with political positions that should be heard. The concepts of autonomy and influence developed by Cohen $(2006,2008)$ can serve as parameters for the analysis of the cases, considering the limits of each one's international performance. How can financial policy contribute to guaranteeing some degree of autonomy for these countries? To what extent, by establishing their position in the international system, would it be possible to exert some kind of influence?

Argentina, Brazil, and Mexico benefited enormously from the prolonged and intense increase in commodity prices, as noted above. ${ }^{3}$ For Argentina in particular, this was a phenomenon of primary importance that provided the government a margin in which to innovate its economic policy from 2003, given the country's unique position in international financial markets after its period of default. Brazil and Mexico continued attracting financial capital and maintained their ability to place bonds in international markets.

\section{ARGENTINA}

The end of the Argentine convertibility regime in January 2002 automatically gave the government back the ability to set monetary and exchange rate policies. Soon after the systemic change, the policy objective was to maintain a competitive currency in order to support economic growth. Different to other crisis episodes, the recovery process in Argentina occurred amid surpluses in the fiscal and current accounts. The fiscal surplus originated due to the increase in national economic growth following the crisis and the surplus in the current account was the result of global economic conditions - initially supported by the domestic recession. When Néstor Kirchner took the reins of the government (2003-2007), the economy was already growing at an intense rate (Labaqui 2012).

After abandoning convertibility, despite the initial intention to widen the discretionary room for economic policy, and consistent intervention from the central bank in the foreign exchange market in order to sustain a depreciated currency, the real move toward interventionism came in early 2007, as described below. Contrary to what many analysts and even IMF economists had predicted, the Argentine economy recovered rapidly following the devaluation of the peso; this growth was supported by the strong bounce in traded goods enhanced by the change in relative prices (see graph 3) (Damill, Frenkel \& Rapetti 2005). The strong growth following the 2002 crisis allowed Argentina to return to levels of production seen in 1998 by as soon as 2005 (Labaqui 2012).

(3) The share of primary goods in total exports is particularly high for Argentina and Brazil. It decreased for Mexico after NAFTA. For Argentina, Brazil and Mexico, agricultural, fuel and mining exports in terms of GDP represented 6\%, 3\% and 6\% respectively in 1990. On average, between 2002 and 2007, these figures were respectively $14.5 \%, 6 \%$ and 5\%. 
Graph 3

Gross Domestic Product, annual growth rates (\%)

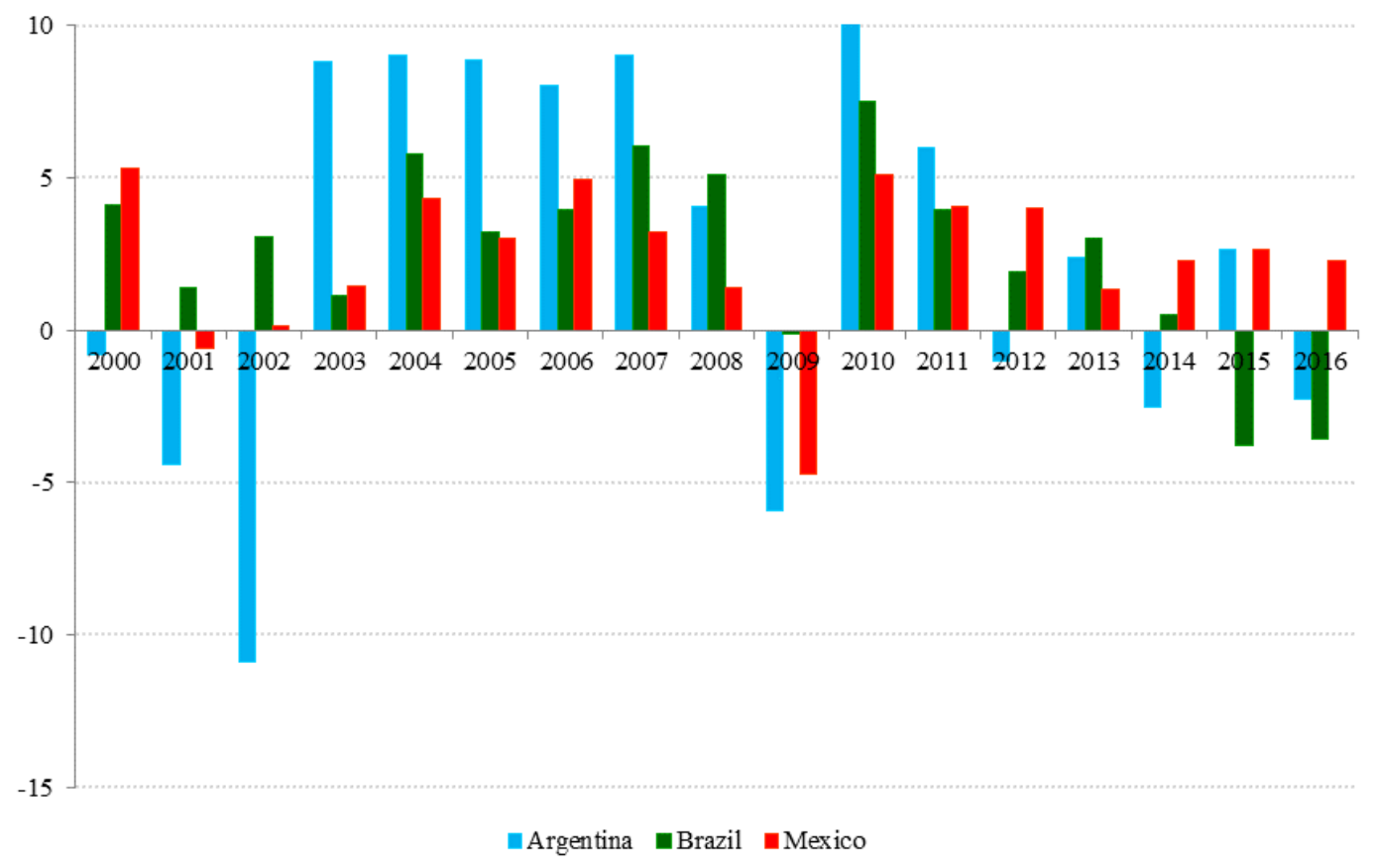

Source: World Bank data base.

Despite being criticized for its economic policy - during the period of fiscal imbalances as well as after 2007 - the Argentine government constantly professed the commitment to paying its debt. Upon taking power in 2003, Kirchner benefited from the default declared by the brief presidency of Adolfo Rodriguez Saá (2011) (Labaqui 2012). The negotiations continued during Eduardo Duhalde's government (2002-2003) and renegotiations were achieved in 2005, as an outcome of favorable international conditions, including interest from the United States President George W. Bush (2001-2009) in testing a package of grand proportions, concerning bail-outs and providing support to creditors (Helleiner 2005). At the same time, in March of 2005, after intense negotiations, the Argentine government announced a restructuring of $76 \%$ of its defaulted debt. Old bonds were traded for new bonds, part of which were denominated in local currency and linked to GDP growth, reducing the stock of public debt by approximately US\$ 67 billion according to publications by the Economic Ministry at that time (Damill; Frenkel; Rapetti 2005, p. 42).

Inflationary pressures had returned to Argentina, pressures which were converted into excuses to restart direct government interventions in different sectors. In 2005, controls were applied to agriculture exports - generating a political conflict that reached an apex in 2007 with fires started by farmers in different regions and around Buenos Aires. Since 2007, state intervention has risen intensely, including - at the expense of further loss of international credibility - interference in the National Institute of Statistics (INDEC), nationalization of 
corporations that had been privatized, a conflict between the administration and the central bank and the strong confrontation with the agricultural sector previously mentioned (Labaqui 2012; Damill; Frenkel 2013). These events worsened the risk perception that international markets held of the country (see Graph 2) and contributed, together with the global crisis, whose effects could still be alleviated by commodity exports, to the outflow of foreign capital. Despite the wide acceptance of debt restructuring by creditors in 2005 and 2010, a group of hold-out creditors - that did not accept the restructuring offer in 2005 - were able to legally prevent Argentina from placing more debt on international markets (Labaqui, 2014).

Labaqui (2012) describes how Argentina attempted to regain the confidence of international markets, and as such, reduce the spread on Argentine bonds, in the process normalizing external debt payments - this despite not being able to bring in the hold-out creditors. The president at the time, Cristiana Fernández de Kirchner, tried to convince observers and investors of the stability of the mechanism of inter public sector financing using resources from national pension funds to increase international reserves.

With the worsening of the international situation, increasing risk aversion and a fall in commodity prices, the Argentine government began implementing more drastic measures. Regarding financial policy, the Kirchner governments (2003-2015) tried to reduce the country's dependence on international finance, including its dependence on multilateral organisms. The attempt to widen the national policy autonomy led to an early payment to the IMF, ${ }^{4}$ the issuing of debt to Venezuela in 2005 (Labaqui, 2012), and via the joint issuing of sovereign bonds with Venezuela in 2006, the Bonus der Sur (Phillips, 2012). Since 2008, access to international markets has been closed, including Venezuela. President Fernández de Kirchner's speech, justifying nationalization based on the 'failure of liberalism' as a result of the crisis of 2008, linked Argentina's policies with the return of interventionism around the world (Datz, 2012).

Moving forward on the institutions, the federal government announced in December 2009 that it would use foreign reserves to pay down part of the private external debt, creating a fund for this, the Fondo Bicentarnario, ${ }^{5}$ which in March 2010 was replaced by another fund that allows government access to reserves. Despite a great deal of backlash, from legal processes to the effective resignation of the governor of Argentina's central bank (BCRA), who at that time refused to implement this policy, the government continued to exchange reserves for 10-year debt securities (Labaqui, 2014).

Due to this set of measures, the Argentine government became its own largest creditor. The transfer of resources from the BCRA for public sector operations, the nationalization of

(4) At the end of 2005, when Brazil announced that it would pay the IMF before the debt's maturity, Kirchner, the Argentine president, followed the example, and proudly announced that it would pay its debt with money borrowed from the central bank. The payment was equal to 9\% of Argentina's total external debt. (http://www.lanacion.com.ar/765314-historico-elpais-saldara-en-un-solo-pago-la-deuda-con-el-fmi).

(5) "El Gobierno utilizará reservas del Banco Central para pagar la deuda" (http://www.lanacion.com.ar/1211935-elgobierno-utilizara-reservas-del-banco-central-para-pagar-la-deuda). 
pension funds (whose funds were critical for maintaining the country's ability to service its debt), in addition to the favorable prices of exported products, were the crucial elements that permitted Argentina to launch a policy of reversing financial integration with the world that had taken place a decade prior.

\section{BRAZIL}

In Brazil, the scenario was still favorable for the government in general terms during the 2008-2009 period. President Lula, who was in the middle of his second term, maintained his high level of popular approval despite the corruption scandals involving important political leaders closely connected to him. The improvements in welfare obtained by lower income groups provided the government with a broad base of support, while also consolidating the idea of Brazil as an emerging country. The worsening of the economic situation following the international crisis was therefore not an acceptable alternative, politically speaking, to the president and his party.

Since Lula's first mandate (2003-2006), a dissatisfied group within his own party criticized the direction of what it considered a 'neoliberal' economic policy. Having achieved a certain level of macroeconomic stability, this group believed it would be necessary to change the policy's objectives and direction. Pro-growth actions could be combined with stability in normal times. When the crisis broke out in 2009, policies aimed at stimulating economic growth were already being executed. As well as an expansionary monetary policy, the three main Brazilian federal banks ${ }^{6}$ were rapidly increasing the concession of credit. At that time, a set of complementary policies to support growth was being created, as a package named the 'new industrial policy', which in fact consisted of a series of fiscal exemptions for specific sectors of the economy as well as incentives for producers with the ability to export ${ }^{7}$.

The transition from President Lula to President Dilma Rousseff marked an important change in the steering of economic policy. In the face of poor economic performance in 2011, more interventionist policies, and policies that were essentially less geared toward ensuring macroeconomic stability, gained importance within the government. At the same time, the relations between the executive branch and the central bank became much closer, to the detriment of the autonomy and credibility of the monetary authority.

Dilma Rousseff's first mandate paved the way for a complete change - that was long awaited by a developmentalist group within the Workers' Party (PT) - regarding the relationship between the Ministry of Finance and the central bank. Since the beginning of the Workers' Party rule, the central bank kept its commitment to macroeconomic stability. During Lula's tenure, conflicts between the two institutions were generally won by the central bank. Between 2003 and 2010 the central bank's board of governors enjoyed a de facto operational

(6) These banks are: Banco do Brasil, the largest commercial Brazilian bank, the BNDES (National Bank for Economic and Social Development), a development bank, and Caixa Econômica Federal, the federal savings bank.

(7) Plano Brasil Maior, launched in 2011, see Motta Veiga et al. (2013). 
autonomy and remained committed to the inflation targeting system regime. Yet, it should be noted that the international economic environment was much more favorable during this period than it was after 2008. Besides, the credibility of economic policy is also an important asset regarding domestic public opinion.

In contrast to the Argentine case, the period that ran from the end of the emerging economies' financial crises in 2002 until the counter cyclical policies were triggered during the crisis in 2008 were not years of fertile financial policy innovation for Brazil. The move toward more interventionists economic policies in Brazil can be distinguished from the case in Argentina in several important aspects, such as the degree of intervention, and the fact that in Brazil an attack on institutions and rules did not occur. Also, different from the Argentine case, Brazil maintained an official discourse concerning the continuity of economic policy and a commitment to stability, praising international integration and using multilateral forums in order to show economic and social improvements. The government also used its speech to denounce the economic policies of more advanced countries that were harmful to the less advanced countries, such as in the case of the so called 'currency wars'.

\section{MEXICO}

Notwithstanding previous domestic reforms and the pro-market orientation of its economic policy, Mexico was not protected from the effects of the 2008 crisis. In fact, the political scene in Mexico is much more complicated than the short list of its presidents in the last years might otherwise suggest. Democracy in Mexico is relatively young compared to Argentina and Brazil, considering the transition of power of the hegemonic party for more than seven decades (1928-2000), the Partido Revolucionario Institucional (PRI), to the Partido Acción Nacional (PAN) with the election of Vicente Fox in 1999. However, twelve years of a PAN administration did not bring significant changes, regardless of the more conservative orientation of the party.

During most of the $19^{\text {th }}$ century, Mexico lived under a very particular political regime. While many Latin America countries were inflicted with instability, coups and military governing crises, the Mexican political system remained relatively stable, dominated by the PRI. The impact of the 70 years of authoritarianism and clientelism on the way in which politics were practiced was so great that it could not be reversed in the twelve years of PAN rule (Flores-Macías, 2013; Wood, 2012). When the global economic crisis broke out in 2008, Mexico was very dependent on the American economy and heavily impacted by the violence created by armed conflict related to drug trafficking. In December of 2012, Enrique Peña Nieto led the PRI back to power, taking with him well-trained technocrats from renowned foreign universities to occupy the posts of the central bank and finance ministry, as had been the case during De la Madrid and Salinas's terms in office. While maintaining the constitutional structure of the Banco de Mexico established in 1993 and the agreements under the NAFTA accord, the design of economic policy would necessarily be different from those established by Argentina and Brazil, towards more orthodox inspired policies. 
In short, the three countries went through the 2000s with very different economic policy structures. These differences are relevant in relation to the general orientation of the ruling parties and the more immediate motivations of economic policy. The priority accorded by each country to its position on the international financial markets when defining their respective economic or financial policies also differs. In the case of Argentina, since the abandonment of convertibility, the demand for autonomy and, therefore, for independence with respect to international actors was crucial. Brazil, however, adopted a much more marketfriendly position, respecting the agreed rules, but trying to reconcile a stable external position with domestic political demands - expansionist by political sectors and entrepreneurs. Finally, Mexico maintained its previous model while adhering to existing alliances, thus remaining fully open to external capital.

The evolution of the nominal exchange rate clearly mirrors these different policy approaches. Taking the average annual value of each currency against the US dollar and building an index from 1995, the trajectories of the three currencies reflect, to some extent, the stability of the economic policies of their respective countries. Graph 3 shows, in the Argentine case, in addition to the devaluation in 2002, the intensity of depreciation of the peso as of 2007, precisely at the rate of the surge of discretionary economic policy. The Mexican peso is more stable, while the Brazilian real adapted more slowly to the exchange rate regime and instabilities of 2001-2002 and the depreciation process that intensified in 2015.

Graph 4

Average nominal exchange rate index (base: $1995=100$ )

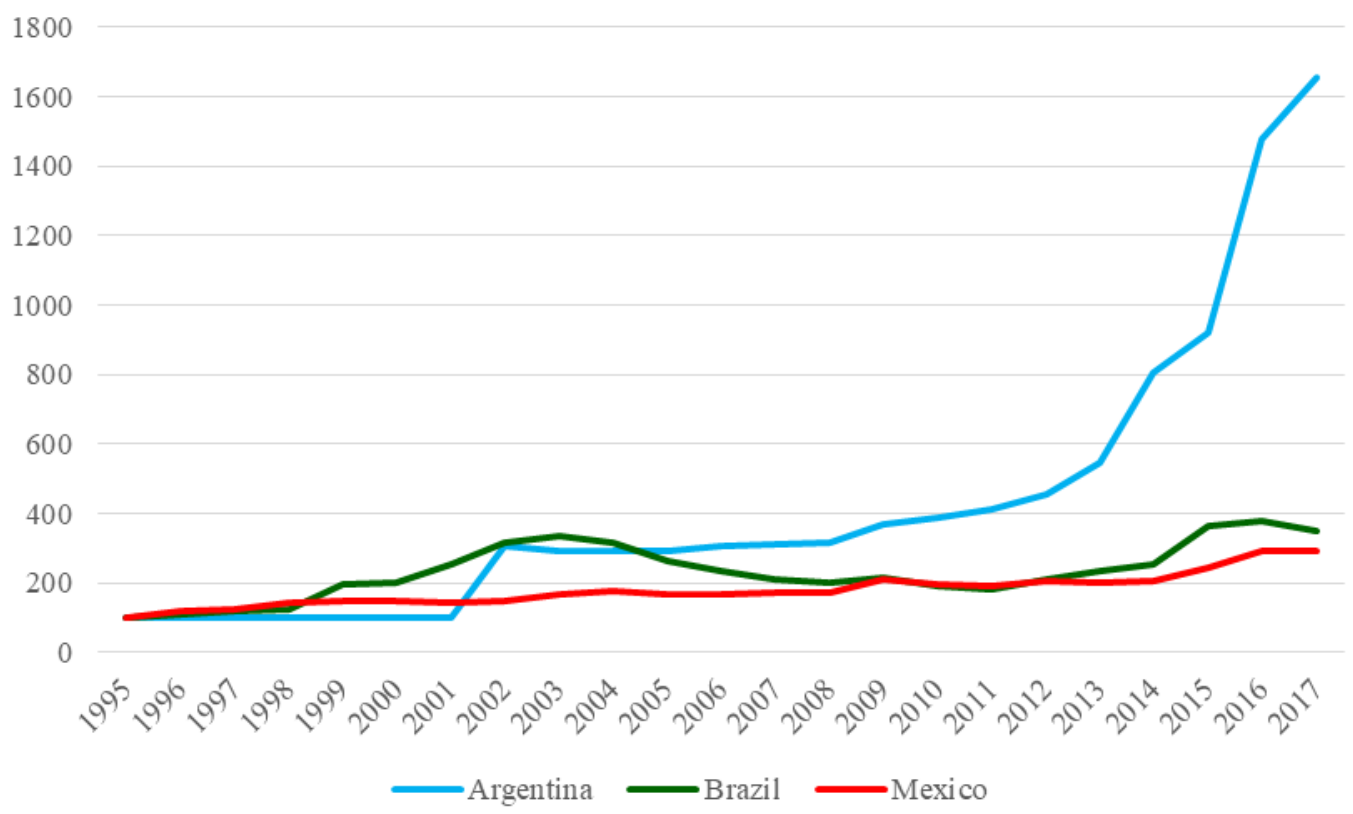

Source: World Bank data base. 
An essential part of the foreign financial policy is conducted through the management of a country's capital flows with the outside world. The depth and breadth of the 2008 crisis brought changes to the degree of financial integration desired and effectively practiced in the world.

\section{Capital control policies}

The literature on capital controls is extensive and diverse, considering different empirical studies that seek to demonstrate the many effects of this type of policy on capital flows and on the risk and expectations related to operations with the countries responsible for it. Abarca, Ramírez and Rangel (2012) review the contributions generated from the resurgence of capital controls after the 2008 crisis and state that there is no single conclusion, since the results point both to benefits and costs - stimuli created by a reduction of capital costs and an increase in the vulnerability of emerging markets, among others. A number of emerging economies have used these types of measures with different objectives. Here the focus is on the case of the three largest Latin American countries.

\section{ARGENTINA}

Due to the lines of credit negotiated after the 2001-02 crisis and the comfortable current account surplus that was maintained for several years, capital control measures remained off the agenda of the Argentine government until 2011. During this year the economic situation deteriorated considerably, bringing the urgent need for devaluation of the peso, which until then had been overvalued in real terms - partially as a result of the manipulation of official statistics measuring inflation and serving as an additional instrument to contain inflation.

President Cristina Fernández de Kirchner was reelected in the first-round in October of 2012 with a significant margin of votes. Shortly after this result, the executive branch introduced a series of measures controlling capital flows and transactions in foreign currencies. Up until that point, the BCRA had been intensely using reserves to defend the valuation of the peso. The return to the use of capital controls had been resumed in Argentina when the global crisis broke, however, it was only in October 2011 that a set of reforms was launched, and the government began to systematically apply controls on foreign exchange operations of companies and individuals, a move which stimulated the return of parallel exchange markets and international capital flight.

The package can be summarized into two groups of measures: one aimed at amplifying the existing supply of foreign exchange, and the other aimed at reducing the demand for foreign exchange ${ }^{8}$.

(8) Source of information on the summarized measures: Economist Intelligence Unit, Country Report Argentina, Dec. 2011, p. 14. 
In order to increase the supply, the principal measures were:

i) Removal of exemptions that allowed oil and mining companies to settle export revenues abroad (up to $70 \%$ for oil companies and $100 \%$ for mining companies). Local settlement of export revenues.

ii) Reduction in the period for repatriating export revenues: beginning at the time when exporters requested authorization from the government - prior to the measure, the count began some time after the operation at customs and when the BCRA guaranteed the transaction.

iii) The creation of a decree obliging insurance companies to repatriate their investments abroad in less than 50 days.

iv) Introduction of new regulations requiring non-residents to purchase domestic assets to carry out foreign exchange operations in the local market.

In order to reduce the demand for foreign exchange the following measures were implemented:

i) Increased use of police and tax control agents to control the presence of individuals arbitrating official access to foreign exchange and price difference on the parallel market (known locally as coleros).

ii) Requirement for individuals and companies that bought more than US\$250 thousand per year in foreign currency to prove the source of their resources. The aim of this measure was to avoid the flight of capital via contado con liquidación, an operation that permits the transfer of money abroad via the purchase of bonds priced in US dollars.

iii) Request for the authorization by the fiscal authorities for the purchase of US dollars as a measure to control tax evasion, but also introduce obstacles to the purchase of dollars, in order to reduce demand. The purchase of dollars for a series of purposes (foreign travel, imports, debt payments) required prior authorization from the federal tax authorities, specifically the Administración Federal de Ingresos Públicos (AFIP), to verify the income of the individuals via their tax statements.

In addition to the more urgent objectives of balancing the external accounts, these measures had a direct impact on the demand of Argentine citizens for foreign currency, a traditional means of escaping crises and surviving periods of high inflation.

\section{BRAZIL}

It should be borne in mind that, regardless of any ideological position of policy makers, one of the main reasons, if not the central one, of controlling capital flows for Brazil was to act on the exchange rate - for example, containing the excessive appreciation of the Brazilian real after 2010 . 
In addition to this objective, the interventions of the Brazilian central bank in the exchange market focused on several other goals, notably the control of inflation and market volatility. The intervention after 2008 took the form of greater regulation of foreign currency derivatives markets and increased taxation to discourage foreign transactions at certain times, or relaxation of capital controls when the objective was to curb currency depreciation. Since the announcement by the US Federal Reserve in May 2013 that it would reduce the supply of liquidity to markets (taper tantrum), the Brazilian real as well as other currencies of emerging countries depreciated greatly - losing nearly $15 \%$ of their value in the three months following the announcement (Chamon; Garcia; Souza 2017, p. 157).

A review of the country's capital and financial account management shows the prevalence of capital controls, in a process that began in the 1990s. Assessing the process of financial liberalization in Brazil, Goldfajn and Minella (2007, p. 350) affirm:

The result of the liberalization process was (a) reduction or elimination of taxes on foreign capital financial transactions and of minimum maturity requirements on loans; (b) elimination of quantitative restrictions on investments by nonresidents in financial and capital markets securities issued either domestically or abroad; (c) permission for residents to issue securities abroad, including debt, without prior approval by the Central Bank; (d) more freedom for residents to invest in FDI and portfolio abroad; and finally (e) the introduction of currency convertibility, initially through the mechanism of international transfers in Reais, whereby residents could transfer their resources abroad through the use of nonresident accounts.

In fact, a phase of macroeconomic stability and favorable performance of external accounts between 2004 and 2007 correspond to a period of greater financial openness in the country. The financial policy measures adopted in Brazil since 2008 can be grouped into three main blocks: capital controls, derivative management techniques (Fritz; Prates, 2014) ${ }^{9}$, and prudential financial regulation. The increase in taxes on financial operations was the main instrument used by Brazilian authorities (Fritz; Prates, 2014, p. 230-231; Chamon; Garcia, 2013, p. 29). Chamon, Garcia and Souza (2017, p. 157-158) summarized the mechanism by which the Central Bank of Brazil intervened in foreign exchange markets beginning in 2013:

On August 22, 2013, the BCB announced a major program of intervention through FX swaps, with the aim of satisfying the excess demand for hedging and providing liquidity to the FX market. The program consisted of daily sales of US\$500 million worth of currency forwards (USD swaps) in the Brazilian markets, that provided investors insurance against a depreciation of the real. These swaps settle in domestic currency and provide investors the very same hedging they would obtain by buying spot dollars and holding them until the maturity of the swap. The program also indicated that on Fridays, the central bank auction offers US\$1 billion on the spot market through repurchase agreements (short term credit lines in USD). The program announcement stated it would last until at least December 31, 2013. On December 18, 2013, the BCB announced that it

(9) Expression created by Fritz and Prates (2013), referring to the term applied in documents elaborated by IMF economists in which capital controls are called euphamistcally, Capital Management Techniques - CMTs. 
would extend the program until at least mid-2014, although the daily interventions were reduced to US $\$ 200$ million. On June 24,2013 , that program was extended until at least end-2014, and eventually extended until March 31, 2015.

The significant intervention in exchange rate markets achieved the objective of reverting depreciation of the real and maintaining the exchange rate relatively stable at an appreciated level. This strategy was considered as innovative for an emerging economy with a floating exchange rate regime, both because of the amount of resources involved and because of the temporary nature of the measures (Chamon; Garcia; Souza, 2017).

The capital control tools that were adopted included the following:

i) Implementation of taxes on financial transactions (Imposto sobre Operações Financeiras - IOF) in foreign exchange operations for the entrance of foreign capital in the country for financial and capital markets applications (Decrees 6.983 and 6.984, of 19 and 20 of October of 2009, respectively).

ii) Implementation of taxes on financial transactions (IOF) in foreign exchange transactions for the entrance of foreign capital in the country for portfolio and fixed income applications (Decrees 6.983 and 6.984, of 19 and 20 of October of 2009, respectively).

iii) IOF collection of $1.5 \%$ assignment of shares that are admitted to trading on a stock exchange located in Brazil, with the purpose of guarantying the issuance of depositary receipts traded abroad (Decree 7.011 of November 18, 2009) (Tax of $1.5 \%$ on the Issuance of DRs into local equities.)

iv) Elevation of the IOF from 2 to $4 \%$ on foreign exchange transactions for portfolio and fixed income applications (Decree 7.323 of October 4th, 2010).

v) Increase in the IOF to $6 \%$ on foreign exchange transactions for portfolio and fixed income applications (Decree 7.412 of December 2010).

vi) Creation of restrictions on movements of foreign investments from portfolio investments to fixed income investments, in October of 2010.

vii) Increase in the IOF to $6 \%$ for new loans taken out abroad and that would fall due in less than one year (Decree 7.456 of March 2011. Broadened, in March 2012, to bonds falling due abroad in less than five years).

Derivative markets were submitted to more stringent legislation in 2011. The main measures can be summarized as:

i) Increase in IOF on net sold exposure (difference between short position and gross long position) of transactions with foreign exchange derivatives from 0.38 to $6 \%$ in October 2010 .

ii) Elimination of loopholes in IOF collection in foreign exchange positions: foreign investors in the forward market are no longer allowed to compose their guarantee margins 
with fixed income securities or guarantees from local banks, which allowed them to avoid the tax.

iii) Indication of the Monetary Board of the Central Bank of Brazil as the responsible agent for regulating the derivatives market in July 2011.

iv) Requirement for all foreign exchange transactions to be priced by the same methodology in July 2011.

Additional measures of prudential regulation were adopted and applied to various types of transactions, but with similar aims:

i) Creation of non-remunerated compulsory deposits, equivalent to $60 \%$ of the short position of banks in the exchange market that exceeded US\$ 3 billion or their equity, whichever was the smallest (to be implemented in 90 days/ Circular 35200 BCB of $29^{\text {th }}$ of August 2011).

ii) Change in the basis of calculation of the compulsory deposit on bank positions sold in excess of US\$ 1 billion (Circular 3,548 BCB) (BCB Circular 3,619 changes the calculation basis again to the amount that exceeds $\mathrm{R} \$ 3$ billion without considering the limit of the (patrimônio de referência) referential equity.)

iii) Change in the calculation of compulsory deposits on short positions of banks that exceeded US\$ 1 billion (Circular 3.548 BCB) (Circular 3.619 BCB again changed the calculation of the value to exceed $\mathrm{R} \$ 3$ billion without considering the equity limit.)

Additionally, as capital controls:

i) Extension of the IOF coverage of $6 \%$ on foreign loans, in the case of renewals of loans already contracted, without settling of foreign exchange position, for a term of up to 360 days (April 2011).

ii) Extension of the IOF coverage of $6 \%$ on foreign loans, in the case of new operations or rolling over of existing loans of up to 720 days (April 2011)

The effectiveness of these measures has given Brazil worldwide fame as one of the countries to apply capital controls more incisively. The difference regarding the type of capital controls imposed by Brazil against the policies adopted by Argentina is noteworthy, since it reflects each country's level of international integration around the year 2010. Argentina was very much marginalized in international financial markets while Brazil was an attractive location for investors. The magnitude of Brazil's foreign exchange reserves also gave policy makers room to maneuver in terms of combining diverse instruments in order to act on various fronts.

The measures were effective in segmenting the Brazilian and global financial markets. Likewise, since 2012, some of these restrictions on capital flows have been reverted, with 
measures meant to increase the inflow of foreign exchange, replacing such restrictions as a result of the strong deterioration of the Brazilian economy (Chamon; Garcia, 2014).

\section{MÉXICO}

In the case of Mexico, the issue of capital controls appears in a different perspective. Regardless of political orientation, membership in NAFTA would, of itself, hinder the use of more radical financial policies. Above all, a political framework in which central bank independence is institutionalized and macroeconomic discipline is considered an asset despite market imperfections, sectoral conflicts, and reform agendas - would not accommodate heavy intervention in financial markets. As such, it is necessary to place the situation in the relative context, remembering that the Mexican financial sector is extremely concentrated, the credit to GDP ratio is low for an economy of its proportion and regulatory deficiencies exist.

The type of capital controls practiced by Mexico in 2010 was quite different from those implemented by Argentina and Brazil. The primary purpose of the controls was to combat illegal drug trafficking business. Limits have been established on cash exchange transactions at US \$ 1500 per person per month. In October 2012, the Ministry of Finance passed a law requiring certain monetary transactions involving money to be reported to its fiscal department and prohibiting a number of other transactions such as high value real estate transactions to be carried out in cash (the same being true for buying and selling gold, jewelry, cars, etc.). Realuyo (2012) explains how transnational criminal organizations based in Mexico, unlike other cases in the world, operate using the formal banking system. Since the 2012 measures, there are no records in the literature of implementation of capital controls. In fact, the comparison of different financial integration indexes based on de jure criteria shows extremely stable behavior from Mexico, contrary to what is seen in the Argentinean and Brazilian cases.

\section{Comparative policies: reversion or adoption of financial openness?}

The fifteen years after the start of the Argentine crisis in 2001-2002 saw an enlarging gap between the financial policy guidelines of the three countries in focus here. Despite being affected by similar macroeconomic disturbances and similar economic conditions at the onset of the global crisis (current account surpluses, balanced public accounts, and growing economies), Argentina, Brazil, and Mexico have pursued quite different economic policy paths since 2010-2011. Not only was the degree of state intervention uneven, but the policy instruments also diverged.

Comparing the different exchange rate and monetary regimes in three time periods (2005, 2008, and 2014) as they appear in the classification of the Annual Report on Exchange Arrangements and Exchange Restrictions (AREAER) of the IMF, Table 1 shows radical changes occurring only for Argentina. Brazil and Mexico, despite remarkable distinctions, as previously mentioned, remain in the same 'field', defined by the system of inflation targeting and floating exchange rate regime - at different scales. As noted earlier, Argentina was 
launched in a sequence of policy changes, while Mexico had the most stable behavior among the three countries. Brazil, while maintaining a commitment to the inflation target, adopted an 'abnormal' expansionary monetary policy between 2011 and 2014, combined with substantial intervention from the central bank in the foreign exchange markets. Thus, with the exception of Mexico, policies became more interventionist as a result, and particularly after 2008.

Table 1

Classification of de facto exchange rate regimes and monetary policy frameworks

2005

\begin{tabular}{|c|c|c|c|}
\hline \multirow[b]{2}{*}{$\begin{array}{l}\text { Exchange rate } \\
\text { arrangements }\end{array}$} & \multicolumn{3}{|c|}{ Monetary policy } \\
\hline & $\begin{array}{c}\text { Monetary aggregate } \\
\text { target }\end{array}$ & $\begin{array}{c}\text { Inflation targeting } \\
\text { regime }\end{array}$ & $\begin{array}{c}\text { Fund-supported or other } \\
\text { monetary program }\end{array}$ \\
\hline Free floating & & $\begin{array}{c}\text { Brazil } \\
\text { Mexico }\end{array}$ & \\
\hline $\begin{array}{l}\text { Managed floating with no } \\
\text { pre-determined path for } \\
\text { the exchange rate }\end{array}$ & & & Argentina \\
\hline \multicolumn{4}{|c|}{2008} \\
\hline \multirow{2}{*}{$\begin{array}{l}\text { Exchange rate } \\
\text { arrangements }\end{array}$} & \multicolumn{3}{|c|}{ Monetary policy } \\
\hline & $\begin{array}{c}\text { Monetary aggregate } \\
\text { target }\end{array}$ & $\begin{array}{c}\text { Inflation targeting } \\
\text { framework }\end{array}$ & Other \\
\hline $\begin{array}{l}\text { Conventional fixed peg } \\
\text { arrangement }\end{array}$ & Argentina & & \\
\hline Independently floating & & $\begin{array}{c}\text { Brazil } \\
\text { Mexico }\end{array}$ & \\
\hline \multicolumn{4}{|c|}{2014} \\
\hline \multirow[b]{2}{*}{$\begin{array}{l}\text { Exchange rate } \\
\text { arrangements }\end{array}$} & \multicolumn{3}{|c|}{ Monetary policy } \\
\hline & $\begin{array}{c}\text { Monetary aggregate } \\
\text { target }\end{array}$ & $\begin{array}{l}\text { Inflation targeting } \\
\text { framework }\end{array}$ & Other \\
\hline Craw-like arrangement & & & Argentina ${ }^{(1)}$ \\
\hline Floating & & Brazil & \\
\hline Free floating & & Mexico & \\
\hline
\end{tabular}

Source: IMF, Classification of Exchange Rate Arrangements and Monetary Policy Frameworks, available at: http://www.imf.org/external/np/mfd/er/2008/eng/0408.htm

(1) The country maintained a de facto anchoring to the US dollar.

Certain game changing elements proposed by Cohen $(2008,2015)$ to analyze the distribution of monetary power throughout the world can be used to tackle the financial policy moves made by the three countries. According to the author, international monetary power is comprised of two dimensions, autonomy and influence.

(...) influence, defined as the ability to shape events or outcomes. In operational terms, this dimension naturally equates with a capacity to control the behaviour of actors - 'letting others have your way', as diplomacy has jokingly been defined. An actor, in this sense, is powerful to the extent that it can effectively pressure or coerce others; in 
short, to the extent that it can exercise leverage or managerial authority. As a dimension of power, influence is the essential sine qua non of systemic leadership.

The second dimension, autonomy, corresponds to the dictionary definition of power as a capacity for action. An actor is also powerful to the extent that it is able to exercise operational independence: to act freely, insulated from outside pressure. In this sense, power does not mean influencing others; rather, it means not allowing others to influence you - others letting you have your way (Cohen, 2008, p. 456).

Cohen's categories can serve as parameters to observe through each state's policies their respective willingness to deepen financial operations within the world's markets and gain a stronger external position. Influence in monetary affairs is a much less evident goal of the countries being analyzed, although exercising autonomy has been a valued asset among them. In this sense, autonomy seems to be a long-cherished possession, particularly in times of political changes. Moreover, as Cohen (2016, p. 122) himself puts in another study while discussing Strange's thoughts on monetary diffusion, "the diffusion of power has been mainly in the dimension of autonomy rather than influence - a point of critical importance. While more actors have gained a degree of insulation from outside pressures, few as yet are able to exercise greater authority to shape events or outcomes." Hence, the aim of this comparative study is to verify which set of policies for each country can be associated with the search for autonomy, while considering their macroeconomic instability and crisis episodes.

The increasingly populist inclination of the Argentine government during Cristina Fernández de Kirchner's presidency was viable as commodity prices ensured some comfort to the balance of payments. In Brazil, there was a clear shift in economic policy in President Dilma Rousseff's first term, amid a policy called by its creators a 'new macroeconomic matrix' for which growth, and not stability as before, would be the priority. The financial policy also aimed at stimulating growth at any cost, which was mainly carried out by domestic credit expansion. The discourse against currency wars (i.e. the effects of emerging countries' currency appreciation as an outcome of foreign capital inflows stimulated by ultra-expansionist monetary policies in the advanced countries, quantitative easing, for example) was an attempt to give more legitimacy to capital control measures and more incisive intervention from the central bank in foreign exchange markets.

Mexico was the most stable country in terms of financial policy. Between 2010 and 2014, Mexico's exchange rate and financial policies suffered very few changes. Banco de México's most important interventions in the foreign exchange markets were concentrated until 2001 and were aimed at controlling exchange rate volatility and stimulating the accumulation of reserves. Economic ties with the United States have determined the dynamics of the exchange rate.

The different financial measures had (have) the expected impacts on the exchange rate trajectory and the accumulation of foreign exchange reserves, directly impacted interest rates, increased the availability of foreign exchange, and helped to rein in inflation. The extensive literature on the subject points to risk management and the search for protection against crises as one of the priority factors for the adoption of capital controls (e.g. Gosh; Qureshi, 2016, 
Goldfajn; Minella 2007; Chamon; Garcia, 2015; Ahmed; Zlate. 2014). But what is the ultimate effect of these financial policies when applied?

Among the indicators of financial integration presented in the literature, the Chinn-Ito index of financial openness ${ }^{10}$ is of particular interest to this study, since it is constructed from institutional variables, that is, de jure information about changes in foreign exchange rules and external accounts of a sample of 182 countries reported annually to the IMF. The indexes for Argentina, Brazil, and Mexico for the period in focus are reproduced in Graph 4. For Argentina, the sharp opening after 1991, the process of closure that occurred after 2001 and the intensification of measures adopted at the end of 2011 are clearly identifiable. Argentina reverted almost all its reforms from the 1990s (Fanelli, 2015). In the case of Brazil, the value of the index calculated in 2018 - with information that covered until the end of 2016 - remained stable (-1.91043 in 1970 moving to -1.20236 in 1998, only turning positive in 2002). For Mexico it is also possible to witness an opening in the data beginning in 1992 when the index goes from -0.1355 to 1.07353 ; it has remained unaltered ever since ${ }^{11}$. The vertical line drawn in 2008 helps make evident the trends for each country: stability for Mexico and closing policies for Brazil and Argentina.

Graph 5

Index of financial openness, selected years

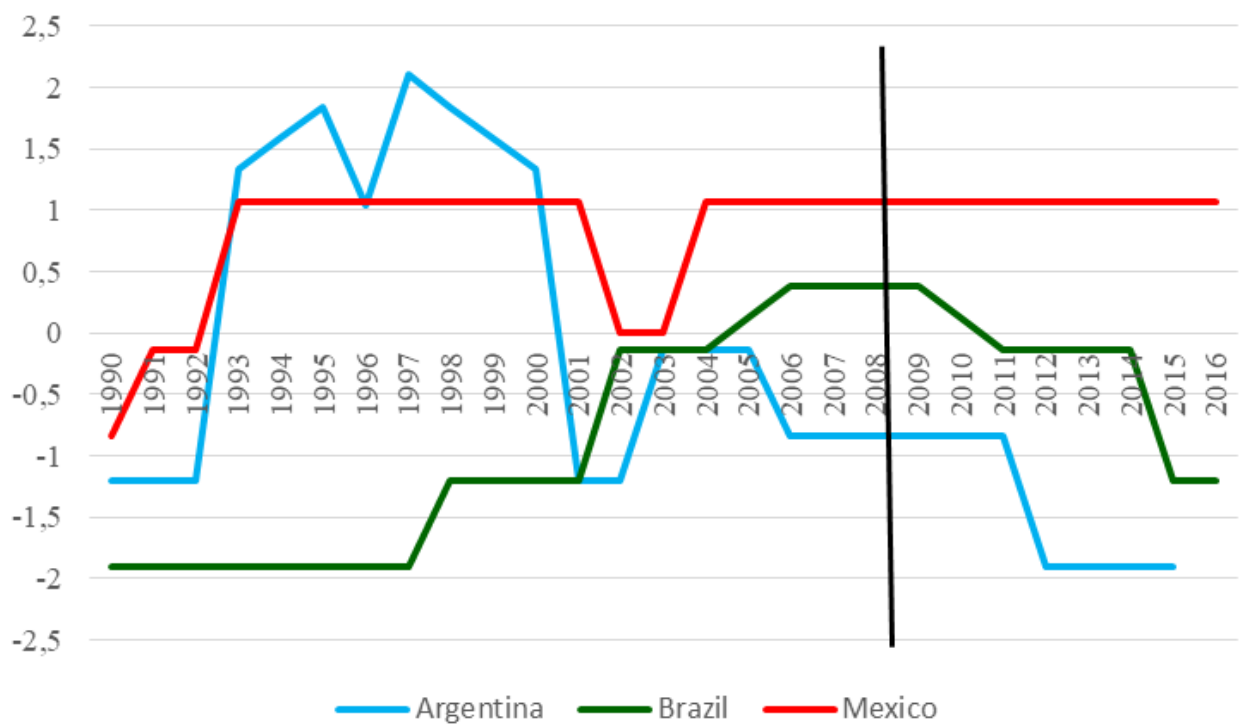

Source: Chinn-Ito http://web.pdx.edu/ ito/Chinn-Ito_website.htm

(10) Chinn-Ito Financial Opening Index. The index is constructed from tabulations of restrictions on crossborder transactions infomed annually in the IMFs AREAER report. Four variables are considered: a variable indicating the presence of multiple exchange rates; a variable indicating restrictions on transactions in current accounts; a variable indicating restrictions on transactions in capital accounts; and a variable that indicates the requirement to renounce export revenues.Every time that the data is updated, the index is recalulated with the entire sample of original variables, including corrected data. Due to this process, the repsective data for prior years is recalculated, so the index is no longer comparible between versions (Chinn; Ito, 2006, 2008).

(11) For the index calculated for 182 countries and information up until 2013, the interval goes from -1.8889 to 2.389668 . 
Based on the same source, AREAER, Fernández et al. (2015) constructed a new data base on financial integration that considers national policies applied to a diverse set of assets, or the differences in measures being applied to the entrance and exit of capital (inflows and outflows). As such, this new data set allows for the disaggregation of the effects of distinct policies. Graph 6 shows the evolution of the aggregated index calculated using this methodology for the period 1995 to 2013 on a scale from 0 to 1, with 1 being the value attributed to the higher level of restrictions on capital flows. With greater detail, the indicators confirm the trajectory of the Chinn-Ito index. Since 2002, Brazil has pushed an agenda of rapid opening, with the apex of this movement occurring in 2006, and thereafter it reapplied strong controls beginning in 2009. Argentina's financial closing can also be clearly identified starting in 2007, as can be the stability of the case of Mexico.

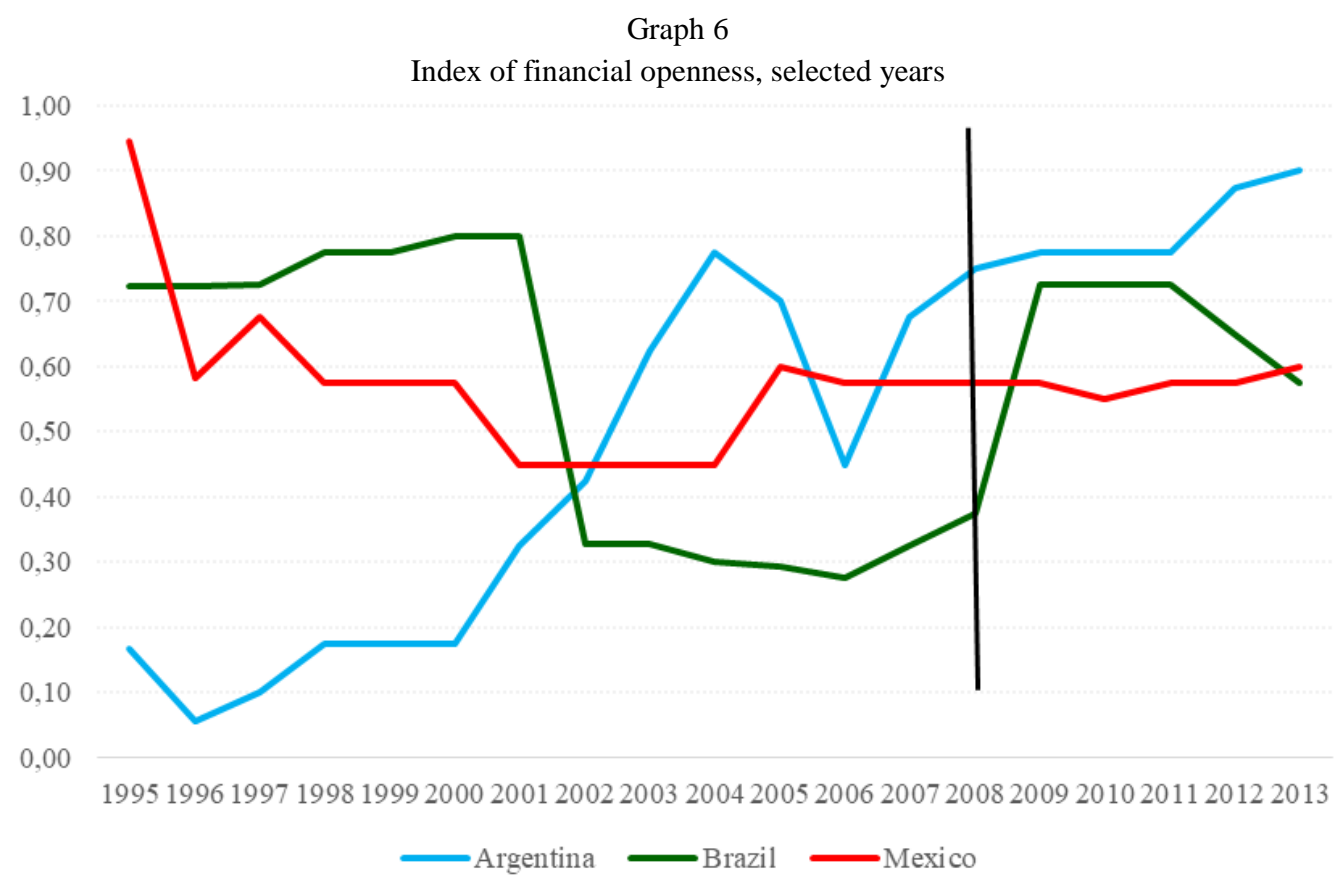

Source: Created using the data from Fernández et al. (2015). New Data Set.

So far, the analysis has shown that Argentina, Brazil and Mexico followed quite different routes with regard to their financial integration policy, despite common elements regarding their liberalizing reforms in the 1990s and the use of a similar economic policy framework - such as the case of the inflation targeting regime, with some degree of fluctuation in the exchange rate for Brazil and Mexico. In the Argentine case, even before the more extreme closing measures adopted at the end of 2011, policymaking was leading to growing financial confinement, intentional, as noted above. For each of the three countries, the desired degree of financial integration was the result of domestic political dynamics. 
The desire for autonomy in monetary and exchange rate policies, as given in Cohen's concept $(2005,2006,2008,2015)$, was expressed differently in each of the three countries. For Argentina, conquering autonomy to conduct its policies meant a process of closure in relation to the international markets. Insulation was being established as the country made deals with creditors, paid off some of the debt and continued with the series of initiatives to control currency flows, in a clear protection strategy.

In the Brazilian case, the Chinn-Ito index shows a relatively low degree of openness for almost the entire two decades, except for the period immediately before the global crisis, which confirms the country's high vulnerability to its own macroeconomic stability. The strengthening of Brazil's image as a rising power is closely related to its ability to attract foreign capital - broadly speaking, not just portfolio capital - which can act as an indicator of its position in the world economy. In the same way, the performance of the domestic economy was essential to the political dynamics. The comings and goings of financial policy illustrate movements of adaptation to the urgencies of each of these related objectives: consolidate Brazil's position as an emerging power and guarantee the continuity of growth, with stimuli to increase domestic demand and income.

"Financial Mexico" is the part of the country that carried out liberal reforms and sustained them; not only is it geographically separated from Mexico on the margins of the modern and more productive economy, but disconnected from the modern part in terms of income, type of economic activities, etc. Sandoval (2011) concludes her extensive study of bank reforms and developments since the early 1980s stating that neoliberal reform in Mexico could be better defined as a political project with economic consequences than as an economic process with political consequences. According to the author, in the design of financial policy, interests were more important than ideas or institutions. The institutional stability of financial and monetary rules in Mexico has high political value. Its maintenance, therefore, is an asset in the country's relations with the rest of the world, NAFTA and with the United States in particular. This process can also be interpreted as the country's desire for power consolidation or autonomy.

In an attempt to organize the analytical elements raised so far, Table 2 intends to mirror Table 1 by proposing a crossed classification of countries' financial integration and the main policy objectives identified. In certain periods, it is difficult to recognize a single policy objective pursued by each of the three countries. Given that the impacts of GFC, as an external shock, have not been overly pronounced in any of the countries, a boost in growth is not always their highest priority. The objectives are not mutually exclusive. 
Table 2

Joint classification of degree of financial openness with main political objectives

\begin{tabular}{|c|c|c|c|}
\hline \multicolumn{4}{|c|}{2005} \\
\hline \multirow{2}{*}{ Political goals } & \multicolumn{3}{|c|}{ Degree of financial openness } \\
\hline & Low & Moderate & High \\
\hline $\begin{array}{l}\text { Macroeconomic } \\
\text { stabilization }\end{array}$ & & & $\begin{array}{c}\text { Argentina } \\
\text { Brazil } \\
\end{array}$ \\
\hline Growth & & Argentina & Mexico \\
\hline International prominence & & & Brazil \\
\hline \multicolumn{4}{|c|}{2008} \\
\hline \multirow{2}{*}{ Political goals } & \multicolumn{3}{|c|}{ Degree of financial openness } \\
\hline & Low & Moderate & High \\
\hline $\begin{array}{l}\text { Macroeconomic } \\
\text { stabilization }\end{array}$ & Argentina & & \\
\hline Growth & & & $\begin{array}{c}\text { Argentina } \\
\text { Brazil } \\
\text { Mexico }\end{array}$ \\
\hline International prominence & & & Brazil \\
\hline \multicolumn{4}{|c|}{2014} \\
\hline \multirow{2}{*}{ Political goals } & \multicolumn{3}{|c|}{ Degree of financial openness } \\
\hline & Low & Moderate & High \\
\hline $\begin{array}{l}\text { Macroeconomic } \\
\text { stabilization }\end{array}$ & & & \\
\hline Growth & Argentina & Brazil & Mexico \\
\hline International prominence & & Brazil & \\
\hline
\end{tabular}

Source: Author's elaboration.

These considerations support the assumption that the search for autonomy in the three cases was related to different degrees of financial integration. For Argentina, autonomy was translated into a way to solve its internal problems, which has corresponded to low degrees of financial openness in critical times since 2008. Brazil, until the recession engendered by macroeconomic destabilization after 2015 and the profound political crisis that ensued, was intensively pursuing international leadership. Financial openness was comparatively higher only during a short period before 2008. The Brazilian search for autonomy dwells on a combination of the consolidation of macroeconomic stability and the amassment of foreign reserves that could bring more relevance in the international financial sphere. Mexico has had a more reticent attitude towards the international arena, being mostly engaged in its domestic and regional issues. Economic stability and growth were important targets to somewhat shield Mexico from its internal challenges and North American influence. 


\section{Concluding remarks: different levels of state intervention in distinct political scenarios}

This comparative exercise was dedicated to investigating the joint influences of external and domestic factors on the financial policymaking of Argentina, Brazil and Mexico in the period 2000-2014, by means of an analysis on economic and political factors. The main argument made is that domestic political demands have played a decisive role in policy design. Using a broad definition of financial policies comprising foreign exchange, monetary and capital control policies, the main idea was to verify whether the three countries have used financial integration as a tool to gain policy autonomy and improve their position in the global financial sphere. More specifically, the argument embodies the belief that Argentina, Brazil, and Mexico, despite confronting similar macroeconomic situations and experiencing relatively stable positions at the beginning of the global financial crisis - surpluses in the current account, balanced fiscal positions, and some degree of economic growth -, pursued distinct financial policy trajectories following the outbreak of the crisis. Not only was the level of state interventionism different, but also the policy instruments that were used were significantly diverse.

It is possible to conclude that the three countries have pursued and gained autonomy the accumulation of international reserves being key to this - to determine the direction of their individual policies. Less vulnerability to external shocks is another essential element in the route to building autonomy. Nevertheless, the experiences differed greatly in each of the countries, as confirmed by indicators of foreign presence in financial transactions in the national economies.

Capital controls were significantly important instruments for both Argentina and Brazil, especially after 2011. For Argentina in particular, these measures appeared to delay a new crisis. In the case of Brazil, capital controls were an alternative to enact exchange rate policy and allowed the country to claim a protagonist role in defending the interests of emerging economies, upon announcing its defensive policies against currency wars. Mexico, on the other hand, remained loyal to the way in which it managed policy prior to the crisis and dealt with US policy spillovers on its economy and other domestic political priorities.

Different policy patterns could be identified, determining different levels of financial integration. The Argentine populist government took a step forward from 2007 and, with that, led the country to a situation of isolation in the international financial markets. The re-election of President Fernández de Kirchner in 2011, coupled with the deterioration in the conditions for raising funds in international markets, created the basis for adopting an increasingly strict control policy on foreign exchange transactions and financial transactions. The Brazilian case can be better understood when its domestic political dynamics are considered. President Dilma Rousseff's inauguration took place just as the economic slowdown began. In addition to the political cost of governing without growth, a number of factors led to the adoption of a new economic policy. The Workers' Party back in power would have the chance to implement a macroeconomic policy model closer to its historical leanings, which was well-regarded by the 
president. In addition, the correlation of forces between the finance ministry and the central bank that, in both of Lula's mandates, had fallen to the monetary authority and the stability proposal, had now reverted in favor of greater control of the executive over monetary and exchange rate policies. Mexico maintained a balanced economic policy in line with institutionally established guidelines amid much deeper challenges on other fronts.

Capital controls became acceptable policy instruments in the context of the crisis as they were being widely used by countries with sound macroeconomic fundamentals and high levels of reserves. The acknowledgment of this type of practice as a possible alternative by the IMF (Gallagher; Ocampo, 2013; Gallagher; Tian, 2017; Ghosh; Qureshi, 2016; Ostry et al., 2011) became more apparent within the international debate on financial integration. Overall, the diffusion of this new official vision did not lead to the unanimous adoption by emerging countries. The three countries examined revealed vastly different alternatives to financial policies, established within their domestic political constraints.

State interventionism within financial policies of the three major Latin American economies would be better understood by a more detailed analysis of the types of instruments used and the relationships among domestic actors in the policymaking process. The change in the IMF's view of financial policies, for example, and changes in the way central banks operate in various parts of the world, do not seem to have been the main determinants of Argentine, Brazilian and Mexican financial policy performance, in terms of format and limits.

\section{References}

ABARCA, G.; RAMÍREZ, C.; RANGEL, J. G. Capital controls and exchange rate expectations in emerging markets. Banco de México Working Papers, n. 2012-08, 2012.

AHMED, S.; ZLATE, A. Capital flows to emerging market economies: a brave new world? Journal of International Money and Finance, v. 48 (B), p. 221-248, 2014. https://doi.org/10.1016/j.jimonfin.2014.05.015.

CHAMON, M.; GARCIA, M. Capital controls in Brazil: effective? Journal of International Money and Finance, 2015. http://dx.doi.org/doi:10.1016/j.jimonfin.2015.08.008.

CHAMON, M.; GARCIA, M.; SOUZA, L. FX interventions in Brazil: a synthetic control approach. Journal of International Economics, 108, p. 157-168. 2017. http://dx.doi.org/10.1016/j.jinteco.2017.05.005,

CHINN, M. D.; ITO, H. What matters for financial development? Capital controls, institutions, and interactions. Journal of Development Economics, v. 81, n. 1, p. 163-192, 2006.

CHINN, M. D.; ITO, H. A new measure of financial openness. Journal of Comparative Policy Analysis: Research and Practice, v. 10, n. 3, p. 309-322, 2008.

COHEN, B. J. The macrofoundation of monetary power. Orfalea Center for Global \& International Studies, 2005. p. 41-75. 
COHEN, B. J. Monetary governance and capital mobility in historical perspective. In: RAINER, G.; MARAUHN, T. (Ed.). The regulation of international financial markets: perspectives for reform. Cambridge: Cambridge University Press, 2006. p. 27-54.

COHEN, B. J. The international monetary system: diffusion and ambiguity. International Affairs, v. 84, n. 3, p. 455-470, 2008.

COHEN, B. J. Currency power. Understanding monetary rivalry. Princeton: Princeton University Press, 2015.

COHEN, B. J. The IPE of money revisited. Review of International Political Economy, v. 24, n. 4, p. 657-680, 2017.

DAMILL, M.; FRENKEL, R.; RAPETTI., M. La deuda argentina: historia, default y reestructuración. Desarrollo Económico, v. 45, n. 178, p. 187-233, jul./set. 2005.

DAMILL, M.; FRENKEL, R. La economía argentina bajo los Kirchner: una historia de dos lustros. Instituto de Transparencia Financiera-ITF, 2013. (Documentos Técnicos, 2013). Available at: http://www.itf.org.ar/pdf/documentos/91 2013.pdf. Accessed: March 19, 2014.

DAMILL, M.; FRENKEL, R. Macroeconomic policies, growth, employment, poverty and inequality in Latin America. In: CORNIA, G. A. (Ed.). Falling inequality in Latin America. Policy changes and lessons. Oxford University Press, 2014.

ECONOMIST Intelligence Unit. Country Report Argentina, Dec. 2011.

ESQUIVEL, G. Mexico's recovery from the global financial crisis. In: WISE C.; ARMIJO, L. E.; KATADA, S. N. (Ed.). Unexpected outcomes: how emerging markets survived the global financial crisis. Washington DC: Brookings Institution Press, 2015.

FANELLI, J. M. Mirando el 2014 en Argentina: ¿dónde está el piloto? Observatorio Económico de la Red Mercosur, Dic. 2013. Available at: http://www.oered.org/index.php?option=com content\&view=article\&id=252\%3Amirandoel-2014-en-argentina-idonde-esta-el-piloto-\&lang=es. Accessed: March 12, 2014.

FLORES-MACÍAS, G. Mexico's 2012 elections: the return of the PRI. Journal of Democracy, v. 24, n. 1, p. 128-141, Jan. 2013.

FRITZ, B.; PRATES, D. M. The new IMF approach to capital account management and its blind spots: lessons from Brazil and South Korea. International Review of Applied Economics, v. 28, n. 2, p. 210-239, 2014.

GALLAGHER, K. P.; OCAMPO, J. A. IMF's new view on capital controls. Economic and Political Weekly, v. 48, n. 12, p.10-13, Mar. 2013.

GALLAGHER, K. P.; TIAN, Y. Regulating capital flows in emerging markets: the IMF and the global financial crisis. Review of Development Finance, 7, p. 95-106, 2017.

GOLDFAJN, I.; MINELLA, A. Capital flows and controls in Brazil: what have we learned? In: EDWARDS, S. (Ed.). Capital controls and capital flows in emerging economies: policies, practices and consequences. University of Chicago Press, 2007. p. 349-419. 
GHOSH, A. R.; QURESHI, M. What's in a name? That which we call capital controls. IMF, Feb. 2016. (Working Paper, 16/25).

IMF. Mexico Financial System Stability Assessment. (IMF Country Report, n. 12/65). 2012a. Available at: https://www.imf.org/en/Publications/CR/Issues/2016/12/31/Mexico-FinancialSystem-Stability-Assessment-25810, Accessed: Jan. 12, 2013.

IMF. Staff Report for the 2012 Article IV Consultation. IMF (Country Report, n. 12/316). 2012b. Available at: https://www.imf.org/en/Publications/CR/Issues/2016/12/31/MexicoStaff-Report-for-the-2012-Article-IV-Consultation-40119, Accessed: Jan. 12, 2013.

IMF. The liberalization and management of capital flows: an institutional view. 2012c. Available at: http://www.imf.org/external/np/pp/eng/2012/111412.pdf. Accessed: Mar. 12, 2013.

LABAQUI, I. Leaving with our own means: the role of financial policy in the Nestor and Cristina Fernández de Kirchner Administrations. In: INTERNATIONAL CONGRESS OF THE LATIN AMERICAN STUDIES ASSOCIATION (LASA), 30, San Francisco, 2012.

LABAQUI, I. Who's afraid of reversing neoliberal reforms? Financial statecraft in Argentina and Venezuela. In: ARMIJO, L. E.; KATADA, S. N. The financial statecraft of emerging powers. Shield and sword in Asia and Latin America. New York: Palgrave Macmillan, 2014. p. 21-46.

MOTTA VEIGA, P.; RIOS, S. P.; NAIDIN, L. C. Políticas comercial e industrial: o hiperativismo do primeiro biênio Dilma. Rio de Janeiro, 2013. (Textos Cindes, n. 35). Disponível em: www.cindesbrasil.org. Accessed: Mar. 9, 2014.

OSTRY, J. D., et al. Managing capital inflows: what tools to use? Apr. 2011. (IMF Staff Discussion Note. SDN/11/06).

RELAYUNO, C. B. It's all about the money: advancing anti-money laundering efforts in the U.S. and Mexico to combat transnational organized crime. Washington DC: Woodrow Wilson International Center for Scholars, May 2012.

SANDOVAL, I. E. Crisis, rentismo y intervencionismo neoliberal en La banca: México (19821999). México: Centro de Estudios Espinosa Yglesias, A.C., 2011.

STANLEY, L. Emerging market economies and financial globalization: Argentina, Brazil, China, India and South Korea. Anthem Frontiers of Global Political Economy, London: Anthem Press, 2018.

STRANGE, S. Finance, information and power. Review of International Studies, 16, p. 259274, 1990.

WIESNER, E. The political economy of macroeconomic policy reform in Latin America: the distributive and institutional context. Northampton, MA: Edward Elgar Publishing, 2008.

WOOD, D. Mexico's democratic challenges. The Washington Quarterly, v. 35, n. 4, p. 93-104, 2012. 